\title{
Early Initiation of Breastfeeding and Exclusive Breastfeeding: A Case Study of Breastfeeding Mothers in Takalar District
}

\author{
Syamsuriyati ${ }^{1,2,}$, Tahir Abdullah ${ }^{3}$, Burhanuddin Bahar ${ }^{3}$, Andi Indahwaty ${ }^{3}$, Veni $\mathrm{Haju}^{3,}$ \\ Ridwan Amiruddin ${ }^{3}$, Toto Sudargo ${ }^{4}$ and Syamsuar Manyullei ${ }^{3}$
}

\author{
${ }^{1}$ Doctoral Student, Public Health Faculty, Hasanuddin University, Makassar, Indonesia \\ ${ }^{2}$ Midwifery Department, Mega Rezky College, Makassar, Indonesia \\ ${ }^{3}$ Public Health Faculty, Hasanuddin University, Makassar, Indonesia \\ ${ }^{4}$ Department of Nutrition and Health, Faculty of Medicine, Public Health, and Nursing, Universitas Gadjah \\ Mada, Yogyakarta, Indonesia
}

\begin{abstract}
The coverage of exclusive breastfeeding in the Takalar District in 2011 was around $57.3 \%$ to $75.4 \%$ which means that people in Takalar District still needs exclusive nutrition and breastfeeding handling. In addition, Early initiation of breastfeeding (EIB) and exclusive breast milk from birth to the age of six months are two important breastfeeding practices in reducing infant mortality rate and increasing exclusive breastfeeding success. This study aims to look at the condition of early initiation of breastfeeding (EIB) and exclusive breastfeeding among breastfeeding mothers in Takalar District. This study was a descriptive study investigating some variables such as socio-demographics, pregnancy history, and early initiation breastfeeding practice. The population consisted of all breastfeeding mothers and samples were chosen randomly (56 subjects). Study findings indicate that the majority of the mothers had been successful in providing exclusive breast milk $(92.9 \%)$. This indicates a very good situation. When viewed from the EIB implementation factor, the proportion of mothers giving birth who had practiced EIB was still low (26.8\%). This indicated that there were respondents who were not successful in practicing EIB but successful in exclusive breastfeeding.
\end{abstract}

Keywords: EIB, Breastfeeding Mother, Exclusive Breastfeeding.

\section{INTRODUCTION}

The Sustainable Development Goals (SDGs) reports that breastfeeding is one of the first steps for a human being to get a healthy and prosperous life. Unfortunately, not everyone knows this. The prevalence of Exclusive ASI in developing countries in 2010 was around $39 \%$. The increase in prevalence of almost all regions in developing countries, namely in 2010 West Africa and central prevalence of Exclusive breastfeeding 28\%, East and South Africa prevalence of $47 \%$ Exclusive breastfeeding, East Asia prevalence of $29 \%$ Exclusive breastfeeding, South Asia prevalence of $45 \%$ Exclusive breastfeeding [1].

In some developing countries including Indonesia, many working mothers do not exclusively breastfeed. In Indonesia, almost 9 out of 10 mothers have given breast milk, but IDAl's research found that only $49.8 \%$ exclusively breastfed for 6 months according to WHO recommendations [2]. Breastfeeding is a natural process and is one of the tasks in infant health care, but in reality not all mothers can carry out the task properly, fail to breastfeed or stop breastfeeding earlier.

*Address correspondence to this author at the Public Health Faculty, Hasanuddin University, Makassar, Indonesia; Tel: 081243883181;

E-mail: syamsuriyatiahmad@gmail.com
This condition not only affects the health of the baby but in some women can also interfere with the concept of self as a mother, because it cannot play an optimal role in the health care of her baby. Mental health disorders in the form of self-concept disorder experienced by women in productive age are often associated with their roles as wives, mothers and workers [3].

National data in Indonesia coverage of exclusive breastfeeding is $61.33 \%$, the highest percentage of coverage of exclusive breastfeeding is in West Nusa Tenggara $(87.35 \%)$ and the lowest percentage is in Papua (15.32\%). While the coverage of exclusive breastfeeding in South Sulawesi in 2016 was 55\% and in 2017 the prevalence of exclusive breastfeeding was $75.45 \%$ [4]. Meanwhile, The Takalar District Health Office stated that the coverage of exclusive breastfeeding in the work area of Takalar District in 2011 was around $57.3 \%$, which increased in 2012 by $64.7 \%$. While the latest data in 2015 showed a range of $75.4 \%$ [5]. This means that Takalar District still needs exclusive nutrition and breastfeeding handling [6-8].

Many relatively easy and inexpensive actions are taken to improve the health and survival of newborns, one of which is Early Initiation of Breastfeeding (EIB) 
and exclusive breastfeeding. This is supported by a recommendation from the United Nation Childrens Fund (UNICEF), that as many as 30,000 infant deaths in Indonesia and 10 million deaths of children under five in the world each year can be prevented through exclusive breastfeeding for 6 months from birth without food, drinks except drugs and vitamins [9].

According to UNICEF, 2010, the earlier the Early Initiation of Breastfeeding (EIB), the lower the risk of neonatal death. Research conducted in Ghana for Early Initiation of Breastfeeding (EIB) after the first 24 hours can risk a 2.4-fold death. Compared to study carried out in Nepal that Early Initiation of Breastfeeding (EIB) before the first 24 hours had a risk of 1.4 times. The authors of the Ghana study estimate that 16 percent of neonatal deaths can be prevented if all newborn babies are breastfed from the first day and 22 percent if breastfed within the first hour of birth. The authors of the Nepal study estimate that Early Initiation of Breastfeeding (EIB) in the first hour of birth can prevent 19 percent of neonatal deaths. The beneficial effects that appear from early breastfeeding remain significant after controlling for other factors known to be associated with death at birth and during infancy. Research by Juliastuti shows that mothers implementing EIB had the possibility of exclusive breastfeeding 6.1 times higher than mothers who did not implement EIB [10].

\section{MATERIAL AND METHODS}

This study is descriptive to solve the problems investigated by describing the state of the provision of Early Initiation of Breastfeeding (EIB) for giving exclusive breastfeeding to infants $0-4$ months at present based on the facts that appear. Sampling using simple random sampling is sampling randomly from members of the population regardless of the strata in the population. This study was conducted by measuring through observation for 4 months. The location of the study was carried out in 2 sub-districts namely South Polongbangkeng and North Polongbangkeng Takalar District. The study was conducted in September 2018 until March 2019. Nursing mothers and newborns began to be observed from birth to infants aged 4 months or 4 months postpartum.

The population in this study were nursing mothers, while the sample in this study were nursing mothers who had babies $0-4$ months. The sample in this study were 47 respondents from 132 breastfeeding people in the month of the study. Sample size was calculated using Lemeshow formula and to minimize the bias and anticipate the drop out (DO), the number of samples is increased by $10 \%$ so that the number of samples taken is at least 52 people. Samples were selected using simple random sampling. In this study the samples involved in this study were 56 people. Processing data in this study using the SPSS program to investigate Early Initiation of Breastfeeding (EIB) conditions and exclusive breastfeeding in nursing mothers in Takalar District.

\section{RESULTS}

The study was conducted in 2 sub-districts namely South Polongbangkeng and North Polongbangkeng, Takalar District. The sample in this study amounted to 56 respondents breastfeeding mothers and newborns began to be observed from birth to infants aged 3 months or 3 months postpartum. Respondents of selected mothers were interviewed regarding the basic characteristics and status of Early Initiation of Breastfeeding (EIB). The results of the analysis are presented as follows:

Table 1: Basic Characteristics

\begin{tabular}{|c|c|c|}
\hline Variable & $\mathbf{n}$ & $\%$ \\
\hline \multicolumn{3}{|l|}{ Age } \\
\hline$\geq 30$ & 27 & 48.2 \\
\hline$<30$ & 29 & 51.8 \\
\hline \multicolumn{3}{|l|}{ Education } \\
\hline Elementary School & 23 & 41.1 \\
\hline Junior High School & 12 & 21.4 \\
\hline Senior High School & 15 & 26.8 \\
\hline College & 6 & 10.7 \\
\hline \multicolumn{3}{|l|}{ Profession } \\
\hline Not working & 52 & 92.9 \\
\hline Working & 4 & 7.1 \\
\hline \multicolumn{3}{|l|}{ Parity } \\
\hline 2 & 25 & 44.6 \\
\hline 3 & 22 & 39.3 \\
\hline 4 & 6 & 10.7 \\
\hline 5 & 2 & 3.6 \\
\hline 7 & 1 & 1.8 \\
\hline \multicolumn{3}{|l|}{ Birth Weight } \\
\hline Normal & 49 & 87.5 \\
\hline LBW & 7 & 12.5 \\
\hline \multicolumn{3}{|l|}{ EIB Status } \\
\hline Yes & 15 & 26.8 \\
\hline No & 41 & 73.2 \\
\hline \multicolumn{3}{|c|}{ Exclusive Breastfeeding Status } \\
\hline Yes & 52 & 92.9 \\
\hline No & 4 & 7.1 \\
\hline Total & 56 & 100 \\
\hline
\end{tabular}

Source: Primary data, 2018. 
Table 2: Proportion of EIB and Exclusive Breastfeeding

\begin{tabular}{|c|c|c|c|c|c|}
\hline \multirow{3}{*}{ EIB } & \multicolumn{4}{|c|}{ Status of Exclusive Breastfeeding } & \multirow{3}{*}{ Total } \\
\hline & \multicolumn{2}{|c|}{ Yes } & \multicolumn{2}{|c|}{ No } & \\
\hline & $\mathbf{n}$ & $\%$ & $\mathbf{n}$ & $\%$ & \\
\hline Yes & 14 & 93.3 & 1 & 6.7 & 15 \\
\hline No & 38 & 92.7 & 3 & 7.3 & 41 \\
\hline Total & 52 & 92.9 & 4 & 7.1 & 56 \\
\hline
\end{tabular}

Source: Primary data, 2018.

Based on the age of the respondents, the majority were less than 30 years old $(51.8 \%)$ and those aged 30 years and over were $48.2 \%$. When reviewing the factors of the education level of the respondents the most only reached the elementary education level as much as $41.1 \%$ and only $10.7 \%$ continued to the Higher Education. On the other hand, as many as $92.9 \%$ of respondents did not work so they could have more time to breastfeed than working mothers. Based on the parity of the respondents, there were $44.6 \%$ of respondents whose parity was twice and $1.8 \%$ of the parity amounted to seven times. Birth results show a good thing. Most of the respondents gave birth to babies with a normal weight of $87.5 \%$. As many as $73.2 \%$ of respondents did not carry out Early Initiation of Breastfeeding (EIB) and only $26.8 \%$ did Early Initiation of Breastfeeding (EIB). As many as $92.9 \%$ of respondents did exclusive breastfeeding and there were $7.1 \%$ of respondents who did not engage in exclusive breastfeeding.

Based on the table above, out of 15 respondents who did EIB there were $93.3 \%$ who did exclusive breastfeeding and from 41 respondents who did not do EIB there were $92.7 \%$ who did exclusive breastfeeding. The high proportion of mothers who succeeded in exclusive breastfeeding even though they did not practice EIB gave different results from the conditions so far. The success of EIB is associated with high opportunities to succeed in giving exclusive breastfeeding.

\section{DISCUSSION}

The mother factor which is the main focus in breastfeeding is the production and expenditure of breast milk or commonly referred to as lactation management. The problem of breastfeeding on the first day after giving birth can be caused by reduced stimulation of the hormone oxytocin. In addition, the psychological factors of postpartum affect lactation. This is caused by physical and physiological changes in the mother which result in psychological changes.
Facts show that the workings of the hormone oxytocin are influenced by psychological conditions. Psychological preparation before breastfeeding is an important factor that influences the success of breastfeeding. Stress Levels, excessive anxiety, unhappiness in mothers play a role in lactation management [11].

Breastmilk is not only functioned as a food but also as a liquid consisting of living cells such as white blood cells, antibodies, hormones, growth factors, enzymes, and other substances which hypothesized can kill pathogens [12]. Exclusive breastfeeding is the provision of only breast milk without other foods and drinks, either in the form of formula milk, oranges, honey, tea water, water, or solid foods such as bananas, papaya, milk porridge, biscuits, and rice porridge. Exclusive breastfeeding, ie immediate milk (approximately 30 minutes after birth) is given until the baby is 6 months old and gives colostrum to the baby as soon as possible $[12,13]$.

Healthy babies generally do not need additional food until the age of 6 months, because until the age of 6 months breast milk is considered sufficient to meet the baby's nutritional needs. In special circumstances it is justified to start giving solid food after the baby is 4 months old but has not reached 6 months. For example, there is an increase in baby's weight that is less than the standard or other signs that indicate that exclusive breastfeeding does not go well, this can occur because of the wrong way of breastfeeding or lack of breastfeeding [14].

A study by Siregar et al. [15] showed that exclusive breastfeeding was influenced by various factors including breast milk not immediately leaving after giving birth or lacking breast milk production, not carrying out Early Initiation of Breastfeeding (EIB), after childbirth, difficulty in sucking, maternal nipples not supporting, working mothers, and the influence of promotion of ASI substitutes. 
One of the benefits of Early Initiation of Breastfeeding (EIB) for mothers is that the baby's sucking on the nipple stimulates the release of the hormone oxytocin which helps the mother's uterus shrink so that postpartum bleeding is resolved faster, stimulates the release of colostrum and increases milk production. In addition, it stimulates the production of the hormone prolactin which increases milk production, provides a relaxing effect, and delays ovulation [16].

Other factors that influence breastfeeding are mother's work. The results of research conducted by Juliastuti shows that mothers who did not work would be more likely to be exclusive breastfeeding [10]. This happens because mothers who work outside the home have a limitation to breastfeed their babies directly. If the working mother has sufficient knowledge about the benefits, the method of storage, including the provision of exclusive breastfeeding, can increase exclusive granting. However, another theory by Notoatmojo indicates that the higher a person's education, the easier it will be to receive information so that more knowledge will be possessed [17]. The low level of education of mothers increases the risk for mothers not to give exclusive breastfeeding [18].

The basic principle of Early Initiation of Breastfeeding (EIB) is without having to be cleaned first, the baby is placed on the mother's chest with the prone position where the baby's ears and hands are in one line, so that skin contact occurs and the baby naturally seeks the breast and begins to suckle. So, the basic principle of EIB is simply to dry the body of a newborn baby with a cloth or towel without having to bathe, without wrapping it then placing it on the mother's chest on his stomach so that there is skin contact with the skin, then give the baby the opportunity to suckle herself in the first hour of birth [19].

Delays in carrying out Early Initiation of Breastfeeding (EIB) cause immaturity of the mammary glands which can result in less milk production and a decrease in milk production. The practice that has been carried out by nursing mothers efficiently increases the emotional bond between babies and mothers who reduce maternal stress $[20,21]$.

Several studies have shown that exclusive breastfeeding can reduce the incidence of infectious diseases such as meningitis, diarrhea and pulmonary infections [22, 23]. In addition, study also proves early supplementary feeding can interfere with breastfeeding and increase morbidity in infants. In addition there is no evidence to support that supplementary feeding at 4 or 5 months of age is more profitable [24].

A previous study showed a relationship between the time of first mother-baby contact with the length of breastfeeding was significant [12]. Babies who are given the opportunity to stop by putting the baby with skin to skin contact for at least one hour, the results are twice as long as breastfeeding. At the age of six months and a year, babies who are given the opportunity to breastfeed early, the results are $59 \%$ and $38 \%$ are still breastfed. Babies who are not given the opportunity to breastfeed early are only $29 \%$ and $8 \%$ who are still breastfed at the same age. Another study was quoted from Fika and Syafiq, Trisakti Medical Journal, 2003 that research in JakartaIndonesia showed that babies were given the opportunity to breastfeed early, the results were eight times more successful in giving exclusive breastfeeding.

Every time a mother feeds her baby, nerve signals from the nipple to the hypothalamus will cause a 10 to 20 -fold increase in prolactin secretion which lasts about 1 hour. But if lactation is not carried out continuously the breast will lose the ability to produce breast milk within one week or more. Production of breast milk can continue if the child continues to suck. Breast milk is continuously secreted into the breast alveoli. Baby suction causes sensory impulses transmitted through the somatic nerve of the mother's nipple to the spinal cord and then to the mother's hypothalamus, which causes nerve signals that aid oxytocin secretion which at the same time when the hypothalamus connects prolactin. Sucking on one breast level not only causes the flow of milk in the breast but also on the other breast cells. What's interesting is that caressing, staring and hearing babies cry often gives enough signals to the mother's hypothalamus to cause milk flow [25].

Dissemination of information regarding exclusive breastfeeding among health workers and the community is still not optimal. Only about $60 \%$ of the community knows information about $\mathrm{ASI}$ and only about $40 \%$ of trained health workers can provide breastfeeding counseling, prevent formula feeding, and prioritize early breastfeeding [26]. Furthermore, a comprehensive regulation is needed regarding exclusive breastfeeding, including the importance of maintaining maternal stress levels so as not to affect the volume of breast milk, arrangements for promotion of formula milk, and lack of support from communities and institutions that employ mothers to breastfeed [27]. 


\section{CONCLUSION AND SUGGESTION}

In conclusion, early initiation breastfeeding may not be associated with exclusive breastfeeding practice since this study shows high proportion of mothers who succeeded in exclusive breastfeeding but not in EIB practice. The success of EIB is associated with high opportunities to succeed in giving exclusive breastfeeding. Dissemination of information regarding exclusive breastfeeding among health workers to the community is still needed. A further study with large samples size may help to explain the phenomenon where high prevalent exclusive breastfeeding practice has low level of early initiation breastfeeding.

\section{REFERENCES}

[1] Cai, X., Wardlaw, T. \& Brown, D. W. Global Trends in Exclusive Breastfeeding. International breastfeeding journal 2012, 7(1): 12. https://doi.org/10.1186/1746-4358-7-12

[2] Yohmi, E., Marzuki, NS., Nainggolan, E., Partiwi G. A. N, Sjarif, $\mathrm{BH}$, and Oswari $\mathrm{H}$. Prevalence of Exclusive Breastfeeding in Indonesia: A Qualitative and Quantitative Study. Paediatrica Indonesiana 2016, 55 (6): 302-8. https://doi.org/10.14238/pi55.6.2015.03

[3] Tedder, J. The Roadmap to Breastfeeding Success: Teaching Child Development to Extend Breastfeeding Duration. The Journal of perinatal education 2015, 24(4): 239-248.

https://doi.org/10.1891/1058-1243.24.4.239

[4] Ministry of Health RI. Profil Kesehatan Tahun 2017. In: KESEHATAN 2017, K. (ed.). Jakarta, Indonesia.

[5] Dinkes Sulsel. Profil Kesehatan Tahun 2015. In: KESEHATAN 2015, D. (ed.). Makassar, Indonesia.

[6] Asmarudin Pakhri, Sirajuddin, and Aini, Nurul. Profil Keluarga Sadar Gizi Dan Hubungannya dengan Status Gizi di Kecamatan Bontomarannu. Media Gizi Pangan 2010, 10(2): 33-38.

[7] Bate, A. I. A., Abdullah, A. Z. and Ansar, J. Determinan Pemberian Asi Eksklusif Di Wilayah Kerja Puskesmas Mangarabombang Kabupaten Takalar. Repository Unhas 2014. 1-11.

[8] Dinkes Sulsel. Rencana Kerja Tahun 2017 Propinsi Sulawesi Selatan. Sulawesi Selatan: Dinas Kesehatan 2017, Indonesia.

[9] UNICEF. Progress for children: achieving the MDGs with equity. UNICEF 2010, Vol. 9.

[10] Juliastuti, Rany. Hubungan Tingkat Pengetahuan, Status Pekerjaan Ibu, dan Pelaksanaan Inisiasi Menyusu Dini dengan Pemberian ASI Eksklusif. Repository Universitas Sebelas Maret 2011, Indonesia.

[11] Su, L.L., Chong, Y.S., Chan, Y.-H., Chan, YS, Fok, D., Tun, $\mathrm{KT}, \mathrm{Ng}, \mathrm{FSP}$, and Rauff, M. Antenatal Education and Postnatal Support Strategies for Improving Rates of Exclusive Breast Feeding: Randomised Controlled Trial. Bmj 2007, 335, 596.

https://doi.org/10.1136/bmj.39279.656343.55
[12] Roesli, U. Mengenal Asi Eksklusif, Niaga Swadaya 2000 , Jakarta: Indonesia.

[13] Nainggolan, M. Pengetahuan Ibu Primigravida Mengenai Faktor-Faktor Yang Mempengaruhi Kualitas Dan Kuantitas Asi Di Puskesmas Simalingkar Medan. Medan: IImu Keperawatan, 2009. Indonesia.

[14] Roesli, U. Panduan Praktis Menyusui. Puspaswara, 2005. Jakarta, Indonesia.

[15] Siregar, A. Faktor-Faktor Yang Mempengaruhi Pemberian Asi Oleh Ibu Melahirkan. Fakultas Kesehatan Masyarakat, Repository USU 2004, Indonesia.

[16] Edmond, K. M., Zandoh, C., Quigley, M. A., Amenga-Etego S, Owosu-Agyei S, and Kirkwood BR. Delayed Breastfeeding Initiation Increases Risk of Neonatal Mortality. Pediatrics 2006, 117 (13): e380-e386. https://doi.org/10.1542/peds.2005-1496

[17] Notoatmodjo, S. Metodelogi Penelitian Kesehatan. Rineka Cipta 2010, Jakarta, Indonesia.

[18] Mardeyanti., Hubungan Faktor Pekerjaan dengan Kepatuhan Ibu Memberikan ASI Eksklusif di RSUP DR. Sardjito Yogyakarta.Tesis. Yogyakarta: Program Pasca Sarjana. Fakultas Kedokteran. Universitas Gadjah Mada, 2007. Indonesia.

[19] Muirhead, P. E., Butcher, G., Rankin, J., and Munlye A. The Effect of a Programme of Organised and Supervised Peer Support on the Initiation and Duration of Breastfeeding: A Randomised Trial. Br J Gen Pract 2006, 56(524): 191-197.

[20] Jayamala, A., Lakshmanagowda, P. B., Pradeep, G., and Gotoru J. Impact of Music Therapy on Breast Milk Secretion in Mothers of Premature Newborns. Journal of clinical and diagnostic research: JCDR 2015, 9(4): CC04-CC06.

[21] Chung, S.-H., Kim, H.-R., Choi, Y.-S., Bae, CW. Trends of Breastfeeding Rate in Korea (1994-2012): Comparison with Oecd and Other Countries. Journal of Korean medical science 2013, 28 (11): 1573-1580.

https://doi.org/10.3346/jkms.2013.28.11.1573

[22] Dewey, K. G., Heinig, M. J. \& Nommsen-Rivers, L. A Differences in Morbidity between Breast-Fed and FormulaFed Infants. The Journal of pediatrics 1994, 126(5 pt 1): 696702.

\section{https://doi.org/10.1016/S0022-3476(95)70395-0}

[23] Lopez-Alarcon, M., Villalpando, S. \& Fajardo, A. BreastFeeding Lowers the Frequency and Duration of Acute Respiratory Infection and Diarrhea in Infants under Six Months of Age. The Journal of nutrition 1997, 127(3): 436443.

https://doi.org/10.1093/jn/127.3.436

[24] Suhardjo. Pemberian Makanan Pada Bayi Dan Anak, Kanisius 2007, Yogyakart: Indonesia.

[25] Pillitteri,A. Buku saku perawatan kesehatan ibu dan anak. EGC 2002, Jakarta: Indonesia.

[26] Suparmi, S. \& Saptarini, I. Determinan Pemberian Asi Eksklusif: Analisis Data Sekunder Survei Demografi Dan Kesehatan Indonesia 2012. Jurnal Kesehatan Reproduksi 2014, 5(1): 15-21.

[27] De Onis, M., Onyango, A. W., Borghi, E., Garza C, Yang H and WHO Multicenter Growth Reference Study Group. Comparison of the World Health Organization (Who) Child Growth Standards and the National Center for Health Statistics/Who International Growth Reference: Implications for Child Health Programmes. Public health nutrition 2006, 9 (7): 942-7.

https://doi.org/10.1017/PHN20062005 